\title{
Economic resilience in developing countries: The role of democracy in the face of external shocks
}

\author{
Salah Ahmed, Mohamed Ali Trabelsi
}

\begin{abstract}
A B S T R A C T
Objective: The objective of this article is to examine the role of democracy in strengthening the resilience of developing economies in the face of exogenous negative external shocks.

Research Design \& Methods: To achieve our research objectives, we used the duration model to estimate how democracy can determine the probable duration of an economic growth spell.

Findings: By examining a panel of 96 developing countries observed in 1965-2015, we found that democracy is a resilience factor, insofar as it helps to support growth spells in the event of negative external shocks. The results show that an improvement in democracy score is associated with an increase in the expected duration of a growth spell. The second finding is that some dimensions of democratic institutions like political participation and egalitarian inclusion can lead to a sustainable economic growth.

Implications \& Recommendations: The benefits of democracy for improving living standards in developing coutries. The study should be subject to further research as more variables that account for major shocks could be considered, such as political and civil unrest, internal conflicts, or natural disasters. These shocks may occur during a growth period and cause very serious disruptive effects.

Contribution \& Value Added: The originality of this work lies in studying the role of democracy in the face of exogenous negative external shocks through the duration model which represents an original empirical study.

Article type: research article

Keywords: $\quad$ resilience; economic growth; developing countries; democracy; survival models

JEL codes: $\quad$ E32, E60, F43, O11

Received: 14 January $2021 \quad$ Revised: 23 July $2021 \quad$ Accepted: 19 September 2021
\end{abstract}

Suggested citation:

Ahmed, S., \& Trabelsi, M.A. (2022). Economic resilience in developing countries: The role of democracy in the face of external shocks. Entrepreneurial Business and Economics Review, 10(1), 23-34. https://doi.org/10.15678/EBER.2022.100102

\section{INTRODUCTION}

The difference between economically successful and unsuccessful countries are not only reflected in growth rates but also in the ability to sustain and support these rates during crises, i.e. their resilience. Facing different common external shocks reflected in changing trade situation, demand for export, and financial flows, the obvious questions are: Why do developing countries react differently? Do democratic institutions support economic growth, despite negative external shocks? How does democracy contribute to improving the resilience of these countries? Finally, what are the specific democratic political institutions that matter the most in explaining the positive effect of democracies on growth spell duration?

In this regard, cross-sectional comparative studies offer only few answers. Indeed, using annual averages, they do not distinguish periods of instability resulting from sudden increases and decreases in growth. They implicitly assume homogeneity of business cycles. In addition, they do not shed light on the reasons why some growth spells tend to shortly fade away.

Such limitations opened the way for a line of research that tries to consider breaking points and growth reversal in these countries. These studies seek to examine - over decades - growth gaps and acceleration (Hausmann, Pritchett \& Rodrik, 2005), the combination of multiple growth regimes (Jerzmanowski, 2006), 
the duration of a growth collapse (Hausmann, Rodriguez \& Wagner, 2008), the beginning and end of growth spells (Jones \& Olken, 2008), and finally, stagnation factors (Reddy \& Minoiu, 2009).

Drawing on this literature and the study of Berg, Ostry and Zettelmeyer (2012), our study aims to examine the relationship between democracy and resilience by focusing on sustained growth spells.

The focus on growth periods provides a clearer view on the growth process than on an analysis of average growth rates and eliminates potential biases resulting from breakpoints. In addition, the emphasis on sustained growth can shed light on the long-term "growth-democracy-resilience" relationship, by-passing the short-term fluctuations of average growth rates.

In this paper, we propose to empirically answer these questions in developing countries using duration models while highlighting the factors that determine the risk inherent to the end of growth periods. This study tests the hypothesis that democracy contributes to supporting the duration of economic growth spells in developing countries. Therefore, we show how democracy contributes to improving the resilience of these countries in the face of external shocks.

Duration analysis allows us to estimate the link between the probability that a growth period will end the following year using a set of variables, representing trade shocks, trade openness, inflation, human capital, investment, and the quality of democratic institutions: electoral democracy index, participation democracy index, egalitarian democracy index, and political institutions.

The rest of the paper is structured as follows. In the first section, we will review the literature on the concept of economic resilience and the role of democratic institutions in economic resilience. The results of the estimates of the effect of democracy on resilience will be presented in the second section, using the duration model applied to 96 developing countries in 1965-2015. Finally, the paper will conclude with a summary of the main results.

\section{LITERATURE REVIEW AND HYPOTHESIS DEVELOPMENT}

\section{Economic resilience}

Before examining the role of democracy in resilience, we must firstly clarify the concept of resilience. Duval and Vogel (2008) define economic resilience as the ability to keep production close to its potential despite a shock. Therefore, resilience has at least two dimensions: the degree to which shocks are absorbed and the speed at which economies return to equilibrium after a shock. Thus, resilience is the ability of different economies to reach their growth potential after a disruptive shock. Whenever a loss of production after a shock and its absorption is significant, the economy is considered less resilient.

The concept of "resilience" denotes this ability to react. It is the ability of a given country to effectively anticipate, absorb, integrate, or overcome the effects of a shock in time. It is defined as the ability of a country to sustain growth periods and to minimize recovery following an adverse shock.

According to Guillaumont (2009), economic resilience is defined as the ability to recover from a shock. The ability to cancel and counter threats to growth that are often linked to economic, political, social, or natural shocks. Berg et al. (2012) define growth resilience as the capacity to sustain growth over a long period. The International Monetary Fund (IMF, 2012) defines resilience as "the ability of an economy to sustain longer and more vigorous periods of expansion and to experience shorter and less severe contraction periods and faster recoveries."

The literature agrees on defining economic resilience as the ability to recover from unfavourable economic conditions or economic shocks. In our study, we will retain the definition which assumes that the resilience of an economy indicates the capacity to support longer periods of expansion.

\section{Democracy's role in economic growth resilience}

Theoretically, the effect of democracy on economic resilience is ambiguous. In fact, proponents of the nondemocracy perspective argue that democracy can hinder growth because government is subject to short-term political pressures, particularly from distributional coalitions.

Olson (1982) argues that democracies are affected by special interest groups. As Olson points out, political competition fundamentally affects how governments manage the economy, thereby influencing the returns, to a productive versus non-productive activity for individuals. In turn, these returns 
directly influence the propensity of economic agents to supply production factors (e.g. labour and capital), specialize, and innovate, helping dictate the course of economic development. The state needs to be insulated from redistributional forces found in democracies (Olson, 1982).

In contrast to these contentions, there are some arguments in favour of the effects of democracy:

- Democracy facilitates the establishment of resilient institutions and policies that mitigate the effects of negative shocks. Indeed, democratic regimes better manage the consequences of external shocks and limit the occurrence of internal shocks, thanks to a better ability to deal with socio-political conflicts. The presence of social freedom and political rights improves the capacity of the economy to adjust to the international environment while democracy promotes better income distribution (Rodrik, 1999).

- Rodrik (1999) and Quinn \& Woolley (2001) gather solid evidence indicating that democratic countries experience less volatility. Acemoglu, Johnson, Robinson and Thaicharoen (2003) highlight the importance of institutions in explaining the differences in instability between countries. Mobarak (2005) found that democracy reduces instability through increased citizen control over the management of economic policy.

Examining a panel of countries, Collier, Goderis and Hoeffler (2006) found that democracy has a mixed effect. It reduces the effects of export price shocks but amplifies shocks linked to the import oil price.

Rodrik (2000) argues that democracy is a factor for long-term growth stability and shock absorption. Democratic institutions encourage political consensus on political responses to external shocks and therefore manage conflicts better than autocracies. Participatory political regimes induce a greater desire for cooperation and conciliation, resulting in economic stability.

Berg et al. (2012) examine the determinants of growth duration in a sample of 140 countries, after identifying periods of strong growth and break points in economic growth in the 1950-2010 period. The results indicate that the duration of economic growth depends on the degree of equality of income distribution, the quality of democratic institutions, trade openness, and macroeconomic stability.

Essers (2012) concludes that democracy has a significant and negative impact on the growth rates observed in 2007-2009 period. In the same context and with examining the political determinants of the magnitude of growth in acceleration and deceleration episodes in 125 countries over the period of 19502010, Kunal, Lant, Sabyasachi and Selim (2018) show that democracies do not necessarily outperform autocracies in a growth acceleration episode. However, the former can avoid large growth collapses.

In conclusion, the link between shocks and economic growth depends on a country's institutional capacity to manage conflicts and adjust the economy to its equilibrium. This capacity depends on the presence of democratic institutions, which promote economic stability through political competition.

\section{RESEARCH METHODOLOGY}

\section{Main hypothesis and expectations}

In line with the literature review, we test the hypothesis that democracy is a resilience factor in that it increases a country's ability to sustain growth periods following an adverse external shock, and we will retain the definition which assumes that the resilience of an economy indicates the capacity to support longer periods of expansion.

Our aim is to estimate the impact of democracy on the probability that a country's period of relatively strong economic growth will come to an end. In other words, we are interested in investigating whether the "waiting period" during which a country remains in distress is associated with democracy.

After a brief overview of democracy indicators, the duration model, and the selected variables, we will present the results of our estimates, which would allow us to determine the impact of democracy on the degree of persistence of sustained economic growth.

\section{Democracy indicators}

The choice of a democracy measure may impact the estimates of democracy's effect on growth. Existing democracy indices are typically subject to considerable measurement error, leading to spurious 
changes in the democracy score of a country even though its democratic institutions do not truly change. Even with year and country fixed effects, changes in democracy may correlate with other changes or respond to current or future economic conditions, raising obvious omitted variable bias concerns (Acemoglu, Johnson, Robinson \& Thaicharoen, 2019).

There is an ongoing debate about the appropriate measure of democracy. This debate highlights the information on which the institutional quality indices are based, but also measurements on a discrete or continuous scale. Our estimates employ continuous measures of democracy used in the literature. These continuous measures are more consistent with the slowly changing nature of institutions described by North (1990), unlike dichotomous measures. To check the sensitivity of our results to different measures of democracy, we use two indices: the Polity2 indicator and the V-dem index.

- The composite index of polity2 uses sub-scores for constraints on the executive branch, competitiveness of political participation and openness and competitiveness of executive recruitment (Marshall, Gurr \& Keith, 2019). The measure, Polity2, comes from the POLITY IV base which is part of a research program at the Center for International Development and Conflict Management (CIDCM) of the University of Maryland. This database covers 186 countries. The Polity index ranges from -10 to 10 (difference between democracy and autocracy) with large positive values representing a greater degree of democracy and large negative values denoting a greater degree of autocracy. Polity IV essentially measures the degree of liberalism of political regimes.

- The V-Dem index ${ }^{1}$ (Varieties of Democracy Dataset version 9) is a new approach to conceptualizing and measuring democracy. It provides a multidimensional and disaggregated dataset that reflects the complexity of the concept of democracy as a system of rule that goes beyond the simple electoral process. The V-Dem project distinguishes between five high-level principles of democracy: electoral, liberal, participatory, deliberative, and egalitarian, and collects data to measure these principles.

To assess the effect of the type of democracy on an economic growth spell duration, we use three dimensions of democracy.

Firstly, the electoral dimension of democracy embodies the core value of making rulers responsive to citizens through competition for the approval of a broad electorate during periodic elections, as captured by Dahl's (1972) conceptualization of "polyarchy."

The electoral principle of democracy ${ }^{1}$ is defined as selecting leaders who are responsive and accountable to citizens through the mechanism of competitive elections as captured by Dahl (1972). This objective is achieved when elections are free and fair, the executive is selected (directly or indirectly) through elections, suffrage is extensive, and political and civil society organizations can operate freely.

To capture these requirements, the Polyarchy index combines indicators on the level of suffrage, freedom to join political and civil society organizations, whether elections are transparent and without systematic irregularities, and whether the chief executive is selected through elections.

The electoral dimension of democracy ${ }^{1}$ seeks to embody the core value of making rulers responsive to citizens, achieved through electoral competition for the electorate's approval under circumstances when suffrage is extensive; political and civil society organizations can operate freely; elections are clean and not marred by fraud or systematic irregularities; and elections affect the composition of the chief executive of the country. In between elections, there is freedom of expression and an independent media capable of presenting alternative views on matters of political relevance.

Secondly, the participatory dimension of democracy ${ }^{1}$ (the participatory democracy index) denotes active participation by citizens in all political processes, electoral and non-electoral. The dimension is motivated by uneasiness about the bedrock practice of electoral democracy: delegating authority to representatives. Then, direct rule by citizens is preferred, wherever practicable. This model of democracy thus takes suffrage for granted, emphasizing engagement in civil society organizations, direct democracy, and subnational elected bodies.

Thirdly, the egalitarian dimension of democracy ${ }^{1}$ (the egalitarian democracy index) holds that material and immaterial inequalities inhibit the exercise of formal rights and liberties and diminish the ability

\footnotetext{
${ }^{1}$ The V-dem institute (University of Gothenburg, Sweden)
} 
of citizens from all social groups to participate. Egalitarian democracy is achieved when rights and freedoms of individuals are protected equally across all social groups; and when resources are distributed equally across all social groups. The distribution of resources should be sufficient to ensure that citizens' basic needs are met in a way that enables their meaningful participation. Additionally, an equal distribution of resources ensures the potential for greater equality in the distribution of power. To make it a measure of egalitarian democracy, the index also takes the level of electoral democracy into account.

\section{Empirical model}

The dependent variable in our econometric model is the probability that sustained economic growth will end. According to Berg et al. (2012) and Abiad, Bluedorn, Guajardo and Topalova (2015), a country is considered to have achieved sustained growth if it records a regular growth rate greater than or equal to $2 \%$ over a period of time.

The duration model used is a proportional failure point model based on Weibull's distribution. The probability density of this distribution is defined by:

$$
f(t ; \gamma ; \delta)=\frac{\gamma}{\delta}\left(\frac{t}{\delta}\right)^{\gamma-1} e^{-(t / \delta)^{\gamma}}
$$

where:

$t>0$ - is the assigned variable or break point;

$\gamma>0$ - is the shape parameter and;

$\delta>0$ - the distribution scale parameter.

Its survival function is defined by: $S(t ; \gamma ; \delta)=e^{-(t / \delta)^{\gamma}}$ and its failure cumulative distribution function is defined by : $F(t ; \gamma ; \delta)=1-e^{-(t / \delta)^{\gamma}}$. The scale parameter is determined by replacing $\delta$ with $\mathrm{t}$ in the cumulative distribution function, which gives us: $F(\delta)=1-e^{-1}=0.632=63.2$ per cent. This shows that the scale parameter $\delta$ represents the point for which $63.2 \%$ of failures are recorded.

If we denote $\lambda(t)$ the instantaneous failure rate, we show that: $\log \lambda(t)=\log \gamma+$ $(\gamma-1) \log t-\gamma \log \delta$. This equation is represented by a line whose abscissa is $\log t$ and the ordinate is $\log \lambda(t)$ (Palisson, 1989). From this relationship, we deduce that the slope of the line has as expression: $p=(\gamma-1)$. The hazard of Weibull's distribution increases with time if $\gamma>1$, decreases if $\gamma<1$ and constant if it is 1 . The estimation of the parameter makes it possible to conclude to an increase, a constancy, or a decrease of the exit probability with the duration of persistence in the growth phase.

We model how the evolution of the period (as a function of different independent variables) affects the probability that it will end at some point in the analysis time. Consistent with the proportional hazard hypothesis, the effect of the independent variables is multiplicative related to hazard (and not related to survival time as in the accelerated failure model). The model assumes that the failure point associated with the duration of period $\mathrm{j}$ is expressed as a product of a random variable $\tau_{j}$ and a proportionality scale which is a function of the weighted sum of a set of $\mathrm{K}$ independent variables $x_{t j}$.

$$
t_{j}=\exp \left(\sum_{k=1}^{K} \beta_{k} x_{k, t j}\right) \tau_{j}
$$

in which $\tau_{j}$ follows a Weibull's distribution with a shape parameter $\gamma$. The coefficients $\beta_{k}$ express temporal ratios which indicate to what extent a variation of a unit of an independent variable would shorten or lengthen the anticipated duration of reference $E\left(\tau_{j}\right)$.

\section{Data and descriptive statistics}

Referring to the database of Berg et al. (2012), our analysis unit (the duration variable) was a growth period. This period was defined as a period of strong growth following a high growth and ending either with a slowdown in growth or with the end of the sample. This approach identified the complete phases of growth as periods of time that meet the following two conditions. Firstly, they begin with a launching, followed by a GDP growth period at least $2 \%$ on average. Secondly, they end with a decrease in growth, followed by a period of average GDP growth less than $2 \%$.

Likewise, incomplete growth periods can be defined as those that meet condition (i) and are still running at the end of the sample. 
Following Berg et al. (2012), growth spells were assumed to be real GDP per capita growth periods that last at least five years. They were to start with an increase of at least $2 \%$ in real GDP per capita and end with a decrease followed by a growth period of less than $2 \%$ on average, or simply with the end of the observation period. The duration of continuous periods of accelerated growth could have been interrupted by exogenous shocks, particularly in the most vulnerable countries. The $2 \%$ growth per capita threshold was already used in the literature and is considered a reasonable growth per capita for low-income countries.

Likewise, "incomplete" growth spells were defined as those which meet the first condition but are still in progress at the end of the sample. A total of 56 full periods and 52 incomplete periods were identified in the sample (Table 1).

Table 1. Duration and frequency of GDP per capita growth spells

\begin{tabular}{|l|c|c|c|c|c|}
\hline \multicolumn{1}{|c|}{ Region } & $\begin{array}{c}\text { Number of } \\
\text { countries }\end{array}$ & $\begin{array}{c}\text { Number of growth } \\
\text { spells completed }\end{array}$ & $\begin{array}{c}\text { Average } \\
\text { duration }\end{array}$ & $\begin{array}{c}\text { Number of growth } \\
\text { spells uncompleted }\end{array}$ & $\begin{array}{c}\text { Average } \\
\text { duration }\end{array}$ \\
\hline Asia & 15 & 8 & 15.6 & 14 & 26.7 \\
\hline Latin America & 22 & 23 & 8.2 & 13 & 19.2 \\
\hline Sub-Saharan Africa & 44 & 18 & 6.4 & 20 & 17.6 \\
\hline MENA & 15 & 7 & 11.9 & 5 & 20.2 \\
\hline
\end{tabular}

Source: own study.

Berg et al. (2012) define a period of complete growth as a period of time that begins with an upward break. It is followed by an average growth rate of at least $2 \%$ and ends with a downward break. The data sources for the variables are shown in Table 2.

Among the variables that indicate exogenous external shocks, we retained terms of trade and change in US interest rates. The chosen democracy variable was Polity IV. This was an index ranging from +10 (democracy) to -10 (autocracy). The democracy index showed the effective presence of institutional rules framing power and the presence of institutions that allow citizens to express their expectations and choose their political elites. Autocracy was characterized by the absence or restriction of political competition and control, the execution of power being slightly restricted by institutions, and leaders are only selected from a political elite.

Table 2. Variables and data sources

\begin{tabular}{|l|l|l|}
\hline \multicolumn{1}{|c|}{ Variables } & \multicolumn{1}{c|}{ Description } & \multicolumn{1}{c|}{ Sources } \\
\hline Vdem & Electoral democracy Index & The V-Dem Institute (University of Gothenburg) \\
\hline Vdempart & Participation democracy index & The V-Dem Institute (University of Gothenburg) \\
\hline Vdemegal & Egalitarian democracy index & Polity IV \\
\hline Polity & Political institutions (P4polity2) & PWT 7.1 (Penn World Table) \\
\hline Inv & Ln (investments,\% of GDP) & Barro Lee \\
\hline Humcap & Ln (primary + secondary years of education) & PWT (Penn World Table) \\
\hline Exchange rate & $\begin{array}{l}\text { Exchange rate, national currency/USD (mar- } \\
\text { ket+estimated). }\end{array}$ & WBI (Wallonie-Bruxelles International) \\
\hline Open & Trade openness =Export +imp\% of GDP & WBI (Wallonie-Bruxelles International) \\
\hline Inflation & Ln (100+inflation rate) & IMF (International Monetary Fund) \\
\hline $\begin{array}{l}\text { Change in terms } \\
\text { of trade }\end{array}$ & $\begin{array}{l}\text { Terms of trade growth (Price level of ex- } \\
\text { ports/Price level of imports) }\end{array}$ & \\
\hline
\end{tabular}

Source: own study.

The study examined a panel of 96 developing countries observed during the 1965-2015 period. Table 1 presents stylized facts about the frequency and duration of growth periods. Most growth periods took place in Africa (around 35\% of all periods, a rate which is proportional to the share of these countries in the sample), while the least growth periods (around $10 \%$ of the total) occured in advanced countries. 
Furthermore, we observed that while it is not unusual to start a growth period, countries differed in their ability to maintain it for longer periods. Compared to other regions, African and Latin American countries had the shortest average growth period, while on average, a full period in Asia lasted about 16 years (Table 1 ).

In Sub-Saharan Africa, the growth periods tended to experience breaks and discontinuities fairly quickly, compared to Asian or MENA countries. These findings can be explained by the political instability of these countries and the armed conflicts during the 1970s, 1980s, and 1990s (Adam, 2002).

Table 3 reports the descriptive statistics of the data across the total period. Conducting a nonparametric estimation ${ }^{2}$ of the survival of growth spells according to political regime, we found that democratic countries had a higher survival rate than authoritarian countries (Figure 1). This finding can be explained by the political stability of democratic countries and their resilience in the face of external shocks.

Table 3. Descriptive statistics of the variables

\begin{tabular}{|l|c|c|c|c|c|}
\hline \multicolumn{1}{|c|}{ Variable } & Obs & Mean & Std Dev & Min & Max \\
\hline p4polity2 & 4453 & -1.153829 & 6.711612 & -10 & 10 \\
\hline Inv & 4624 & 2.889192 & 0.641048 & -0.3232415 & 4.383527 \\
\hline Vdem_part & 4570 & 0.1837567 & 0.1558495 & 0.009 & 0.805 \\
\hline Vdem_poly & 4570 & 0.3258193 & 0.2268712 & 0.008 & 0.929 \\
\hline Vdem_egal & 4570 & 0.227844 & 0.1607496 & 0.017 & 0.836 \\
\hline Inflation rate & 3444 & 36.71384 & 495.9857 & 17.64042 & 23773.13 \\
\hline Hum cap & 4233 & 1.198931 & 0.7997237 & -3.684944 & 2.47215 \\
\hline Open & 4625 & 64.82642 & 44.01233 & 4.111102 & 433.0451 \\
\hline Exhange rate & 4411 & 334.2211 & 1344.71 & $8.10 \mathrm{e}-14$ & 18612.92 \\
\hline Changes in terms of trade & 4317 & 0.0562438 & 10.88022 & -114.7957 & 91.88754 \\
\hline
\end{tabular}

Source: own study.

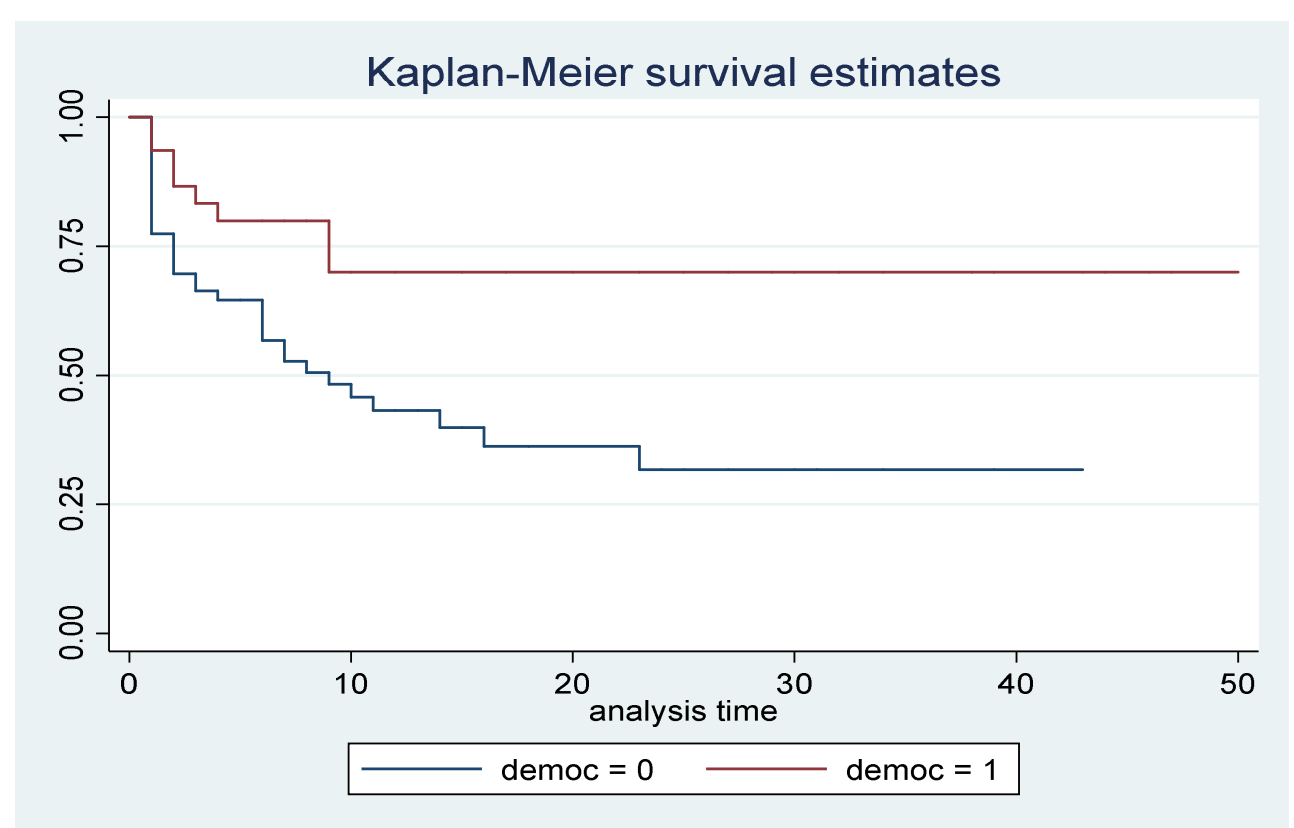

Figure 1. Nonparametric estimation of the survival of growth spells according to political regime Source: own elaboration.

\footnotetext{
2 The Kaplan-Meier estimator is a non-parametric statistic used to estimate the survival function from lifetime data. Their curve shows the probability of an event at a respective time interval. The curve should approach the true survival function for the population under investigation, provided the sample size is large enough.
} 


\section{RESULTS AND DISCUSSION}

After arriving at the descriptive analysis of the data in Table 3, which shows a strong heterogeneity in the sample, we estimated a maximum likelihood of survival models in a parametric regression by using Weibull's survival distribution.

The results in Table 4 show the regression coefficients, which can be interpreted as "risk ratios:" the factor by which a risk rate increases when the covariate increases by unit one. For example, a risk ratio of 1.05 means that a change of one unit in the regressor increases the risk of slowing growth by $5 \%$ in the following period. A risk ratio of 1 means that there is no effect, and a risk ratio less than one denotes a "growth protection effect."

The dependent variable represents the risk that the growth phase will be interrupted. The coefficient associated with the independent variable represents the change in the probability that the growth episode ends next year for a variation of one unit in the given independent variable. As expected, negative external shocks were associated with higher growth failure rates. These negative exogenous external shocks negatively affected the duration of a growth period. Real negative external shocks were particularly costly in terms of production in developing countries.

The results highlighted the beneficial effects of improving political institutions (making them more democratic). Democracy significantly extended the duration of growth periods. This promoted more resilient and more sustainable growth.

A proportional hazard model with time varying covariates was used to relate the probability that a growth spell will end to a variety of economic and political variables. A hazard ratio of 0.9 means that a unit change in the regressor decreases the expected time of duration by $10 \%$. A hazard ratio of 1 means there is no effect and a ratio of 1.1 means it increases expected duration by $10 \%$. We tested the probability that the true hazard ratio equals 1.

The results reported in Table 4 support the hypothesis that democratic countries tended to respond better to negative external shocks. These results corroborate with those of Essers (2012) who showed the ability of democratic countries to face economic crisis, specifically the 2008 crisis.

All proxies for institutions were enterd into the model with statistical significance and expected signs. The results also highlighted the beneficial effects of improving political institutions (making them more democratic) and terms of trade. A one-point improvement in the democracy score was associated with at least $8 \%$ increase in the expected duration of a growth spell. Lower inflation generally extended growth periods. On the other hand, an increase in investment rate and a greater trade openness had no significant effect. Table 4 shows that - while the signs of these two variables are positive - human capital and overvaluation of the exchange rate are statistically insignificant.

Our estimates validated the hypothesis that democracy is a resilience factor. Resilience expresses institutional ability to support longer expansion phases. This finding is consistent with those of some authors like Berg et al. (2012), Ostry, Berg \& Tsangarides (2014), and Abiad et al. (2015). These authors conclude that negative external shocks and macroeconomic volatility negatively correlate with the length of growth periods and that democracy supports growth periods. Our results support their findings in focusing on the role of some democratic indicators like political participation and egalitarian inclusion, which significantly sustains the duration of growth periods and corroborate with those of some authors such as Berg et al. (2012) who find that the duration of growth episodes is positively associated with lower income inequality, democratic institutions, and macroeconomic stability. 
Table 4. Democracy and the duration of growth spells

\begin{tabular}{|c|c|c|c|c|}
\hline Equations & (1) & $(2)$ & (3) & (4) \\
\hline Dependent variable & $\begin{array}{c}\text { Analysis time } \\
\text { when record ends }\end{array}$ & $\begin{array}{c}\text { Analysis time } \\
\text { when record ends }\end{array}$ & $\begin{array}{c}\text { Analysis time } \\
\text { when record ends }\end{array}$ & $\begin{array}{c}\text { Analysis time } \\
\text { when record ends }\end{array}$ \\
\hline Inv & $\begin{array}{c}1.067 \\
(\mathbf{0 . 0 6 4 5 )} \\
\end{array}$ & $\begin{array}{c}1.063 \\
(\mathbf{0 . 0 6 3 2}) \\
\end{array}$ & $\begin{array}{c}1.063 \\
(\mathbf{0 . 0 6 2 5 )} \\
\end{array}$ & $\begin{array}{c}1.076 \\
(\mathbf{0 . 0 6 0 6 )} \\
\end{array}$ \\
\hline Inflation & $\begin{array}{l}1.030^{* * *} \\
(0.0110)\end{array}$ & $\begin{array}{l}1.034^{* * *} \\
(0.0118)\end{array}$ & $\begin{array}{l}1.038^{* * *} \\
(0.0125)\end{array}$ & $\begin{array}{l}1.039^{* * *} \\
(0.0129)\end{array}$ \\
\hline $\begin{array}{l}\text { Change in Terms of } \\
\text { trade }\end{array}$ & $\begin{array}{c}0.969^{* *} \\
(0.0140)\end{array}$ & $\begin{array}{l}0.966^{* *} \\
(0.0140)\end{array}$ & $\begin{array}{c}0.965^{* *} \\
(0.0138)\end{array}$ & $\begin{array}{c}0.967^{* *} \\
(0.0135) \\
\end{array}$ \\
\hline Polity & $\begin{array}{l}0.923^{* *} \\
(0.0325)\end{array}$ & & & \\
\hline Exchange rate & $\begin{array}{c}0.998 \\
(0.0014) \\
\end{array}$ & $\begin{array}{c}0.998 \\
(0.0013) \\
\end{array}$ & $\begin{array}{c}0.998 \\
(0.0014) \\
\end{array}$ & $\begin{array}{c}0.998 \\
(0.0013) \\
\end{array}$ \\
\hline Humcap & $\begin{array}{c}0.786 \\
(0.2677) \\
\end{array}$ & $\begin{array}{c}0.796 \\
(0.2732) \\
\end{array}$ & $\begin{array}{c}0.796 \\
(0.2743) \\
\end{array}$ & $\begin{array}{c}0.817 \\
(0.2907) \\
\end{array}$ \\
\hline Open & $\begin{array}{c}0.998 \\
(0.0043) \\
\end{array}$ & $\begin{array}{c}0.999 \\
(0.0044) \\
\end{array}$ & $\begin{array}{c}0.999 \\
(0.0042) \\
\end{array}$ & $\begin{array}{c}1.001 \\
(0.0043) \\
\end{array}$ \\
\hline Vdem & & $\begin{array}{c}0.788^{* *} \\
(0.0861)\end{array}$ & & \\
\hline Vdempart & & & $\begin{array}{l}0.967^{* *} \\
(0.0154)\end{array}$ & \\
\hline Vdemegal & & & & $\begin{array}{l}\mathbf{0 . 6 9 3}^{* *} \\
(0.1150)\end{array}$ \\
\hline Observations & 794 & 794 & 794 & 794 \\
\hline Success/failure & $67 / 27$ & $67 / 27$ & $67 / 27$ & $67 / 27$ \\
\hline Log-likelihood & -67.755 & -67.866 & -67.934 & -67.631 \\
\hline
\end{tabular}

Notes: The table reports hazard ratios. where a hazard ratio larger than 1 implies that increases in the associated variable shortens spells, while a ratio smaller than 1 implies that the covariate has a "protective" effect, i.e., it helps sustain the spell. $*, * *, \& * * *$ denote statistical significance at the $10 \% .5 \%$ and $1 \%$ levels respectively. P-values are given in brackets under the coefficient estimates.

Source: own study.

\section{CONCLUSIONS}

The duration of current accelerated growth periods can be interrupted by exogenous negative shocks, particularly in the most vulnerable countries. According to our hypothesis, democracy impacts the length of growth periods in developing countries vulnerable to exogenous negative shocks, thus showing that democracy is likely to protect the growth process of these countries.

On the other hand, our results show that democracy significantly extends the duration of growth periods. This promotes more resilient and sustainable growth. An improvement in the democracy score is associated with an increase in the expected duration of a growth spell. We should point out that our analysis of duration only considers periods of growth but not economic stagnation. Therefore, we cannot predict the crisis of stagnation in countries that have started a democratic political transition such as Tunisia.

The factors that cause sustained growth usually do not explain why a country is stagnant. The dynamics of stagnation are difficult to predict. It can even start with the democratization of political institutions. The case of Tunisia is a better example where the crisis of economic stagnation has continued for 10 years for several political and identity reasons.

Firstly, the impact of political democratization on economic growth is not immediate and takes a lot of time. Secondly, the building of democratic economic institutions and structural reforms face resistance from vested interests, lobbies, and other groups opposed to reform. The third obstacle is related to political instability and social unrest. 
Despite the heterogeneity of growth experiences among countries in transition, democracy is a very useful factor in immunizing the country against external shocks such as a vaccine that inhibits the development of a virus and develops antibodies while avoiding the complications of contamination. Our results support the idea that democracies do better than autocracies in managing conflicts caused by external shocks.

However, our study may be subject to further research. More variables that account for major shocks can be considered, such as political and civil unrest, internal conflicts, or natural disasters like the Covid-19 pandemic. These shocks may occur during a growth period and cause very serious disruptive effects.

\section{REFERENCES}

Abiad, A., Bluedorn, J., Guajardo, J. \& Topalova, P. (2015). The Rising Resilience of Emerging Market and Developing Economies. World Development, 72, 1-26. https://doi.org/10.1016/j.worlddev.2015.02.005.

Acemoglu, D., Johnson, S., Robinson, J. \& Thaicharoen, Y. (2003). Institutional causes, macroeconomic symptoms: volatility, crises and growth. Journal of Monetary Economics, 50(1), 49-123. https://doi:10.1016/\$03043932(02)00208-8

Acemoglu, D., Naidu, S., Restrepo, P. \& Robinson, J.A. (2019). Democracy does cause growth. Journal of Political Economy, 127(1), 47-100. https://doi.org/10.1086/700936

Adam, M. (2002). Guerres africaines. Etudes rurales, 167-186. https://doi.org/10.4000/etudesrurales.7978

Berg, A., Ostry, J. \& Zettelmeyer, J. (2012). What makes growth sustained?. Journal of Development Economics, 98, 149-166. https://doi.org/10.1016/j.jdeveco.2011.08.002

Collier, P., Goderis, B. \& Hoeffler, A. (2006). Shocks and growth: adaptation, precaution and compensation. Oxford: Department of Economics, Oxford University.

Dahl, R. (1972). Polyarchy: participation and opposition. New Haven: Yale University Press.

Duval, R. \& Vogel, L. (2008). Economic resilience to shocks: The role of structural policies. OECD Journal: Economic Studies, 2008(1), 1-38.

Essers, D. (2012). Democracy and external shock resilience in developing countries: evidence from the great recession. (Working Paper). Institute of Development Policy and Management, University of Antwerp.

Guillaumont, P. (2009). A retrospective Economic Vulnerability Index. Policy Brief Series. 3. FERDI. Retrieved from: http://byind.ferdi.fr/en. on January 14.

Hausmann, R., Pritchett, L. \& Rodrik, D. (2005). Growth accelerations. Journal of Economic Growth, 10, 303-329. https://doi.org/10.1007/s10887-005-4712-0

Hausmann, R., Rodriguez, F. \& Wagner, R. (2008). Growth Collapses. In Reinhart, C.M., \& Vehg, C.A. (eds.), Money, crises, and transition: Essays in honor of Guillermo A. Calvo (376-428). Lonodon: MIT Press.

Jerzmanowski, M. (2006). Empirics of hills, plateaus, mountains and plains: A Markov-switching approach to growth Journal of Development Economics, 81(2), 357-38. https://doi.org/10.1016/j.jdeveco.2005.05.005

Jones, B.F. \& Olken, B. (2008). The Anatomy of Start-Stop Growth. The Review of Economics and Statistics, 90(3), 582-587. http://www.mitpressjournals.org/doi/pdf/10.1162/rest.90.3.582

Kunal, S., Lant, P., Sabyasachi, K. \& Selim R. (2018). Democracy Versus Dictatorship? The Political Determinants of Growth Episodes, Journal of Development Perspectives 2(1-2), 3-28. https://doi.org/10.5325/jdevepers.2.1-2.0003

Marshall, M.G., Gurr T.R. \& Keith, J. (2019). Polity IV Project: Political Regime Characteristics and Transitions, 1800-2018, Dataset Users' Manual. CSP. Retrieved from: http://www.systemicpeace.org/inscr/p4manualv2018.pdf. On January 14, 2021.

Mobarak, A.S. (2005). Democracy, Volatility, and Economic Development. Review of Economics and Statistics, 87(2), 348-361. https:// doi: 10.1162/0034653053970302

North, D.C. (1990). Institutions, Institutional Change and Economic Performance. Cambridge: Cambridge University Press.

Olson, M. (1982). The rise and decline of nations: economic growth, stagflation, and social rigidities. New Haven: Yale University Press. 
Ostry, J.D. Berg, A. \& Tsangarides, C.G. (2014). Redistribution, inequality and growth (IMF Staff Discussion Note, SDN1402). Retrieved from: https://www.imf.org/external/pubs/ft/sdn/2014/sdn1402.pdf on January 14, 2021.

Palisson, F. (1989). Détermination des paramètres du modèle de Weibull à partir de la méthode de l'actuariat. Revue de Statistique Appliquée, 37(4), 5-39. Retrieved from : http://www.numdam.org/article/RSA_1989_37_4_5_0.pdf

Quinn, D. P. \& Woolley, J.T. (2001). Democracy and National Economic Performance: The Preference for Stability. American Journal of Political Science, 45(3), 634-657. https://doi.org/10.2307/2669243

Reddy, S. \& Minoiu, C. (2009). Real income stagnation of countries 1960-2001. Journal of Development Studies, 45, 1-23. https://doi.org/10.1080/00220380802265249

Rodrik, D. (1999). Where did all the growth go? External shocks, social conflict and growth collapses. Journal of Economic Growth, 4(4), 385-412. https://doi.org/10.1023/A:1009863208706

Rodrik, D. (2000). Participatory politics, social cooperation, and economic stability. American Economic Review, 90(2), 140-144. https:// doi: 10.1257/aer.90.2.140

\section{Appendix: List of countries}

\begin{tabular}{|l|l|l|l|l|}
\hline \multicolumn{1}{|c|}{ Africa } & \multicolumn{1}{c|}{ Africa } & \multicolumn{1}{c|}{ MEtin America } & \multicolumn{1}{c|}{ Asia } \\
\hline Gambia. The & Congo. Dem. Rep. & Guatemala & Syria & Malaysia \\
\hline Ghana & Chad & Honduras & Bahrain & Indonesia \\
\hline Sudan & Guinea-Bissau & Ecuador & Qatar & Thailand \\
\hline Guinea & Mauritius & Nicaragua & Saudi Arabia & Philippines \\
\hline Malawi & Rwanda & Guyana & Egypt & Korea. Republic of \\
\hline Cameroon & Sierra Leone & Haiti & Libya & Vietnam \\
\hline Nigeria & Togo & Costa Rica & Yemen & Taiwan \\
\hline Gabon & Lesotho & Brazil & Morocco & Laos \\
\hline Central African Republic & Ethiopia & Chile & Iraq & Cambodia \\
\hline Equatorial Guinea & Mali & Uruguay & Jordan & Singapore \\
\hline Seychelles & Botswana & Venezuela & Kuwait & Bangladesh \\
\hline Kenya & Ivory Cost & Panama & Tunisia & Nepal \\
\hline South Africa & Liberia & Peru & Iran & India \\
\hline Mozambique & Angola & Mexico & Algeria & Sri Lanka \\
\hline Congo. Republic of & Tanzania & Jamaica & Lebanon & Pakistan \\
\hline Senegal & Uganda & Dominican Republic & Oman & \\
\hline Zimbabwe & Mauritania & Argentina & United Arab Emirates & \\
\hline Namibia & Benin & Colombia & Turkey & \\
\hline Burkina Faso & Cape Verde & Paraguay & & \\
\hline Niger & Zambia & El Salvador & & \\
\hline Madagascar & Burundi & Bolivia & & \\
\hline
\end{tabular}




\section{Authors}

Contribution share of authors is equal and amounted to $50 \%$ for each of them.

\section{Salah Ahmed}

Full Professor in Economics, University of Tunis El Manar, Faculty of Economics and Management of Tunis, Campus universitaire Farhat Hached, 2092, Tunisia.

Correspondence to: e-mail: Salah.Ahmad@fsegt.utm.tn or ahmedtun7@yahoo.fr ORCID (1) http://orcid.org/0000-0002-3735-7092

\section{Mohamed Ali Trabelsi}

Full Professor in Quantitative Methods, Director of Econometrics Applied to Finance Laboratory.

Correspondence to: Prof. Mohamed Ali Trabelsi, PhD, University of Tunis El Manar, Faculty of Economics and Management of Tunis, Campus universitaire Farhat Hached, 2092, Tunisia; e-mail: medali.trabelsi@fsegt.utm.tn or daly1704@yahoo.fr

ORCID (1) http://orcid.org/0000-0003-2307-323X

\section{Acknowledgements and Financial Disclosure}

The authors would like to thank the anonymous referees for their useful comments, which contributed to increase the value of this article; they would also like to express their gratitude to Dr. Jakub Janus from EBER and to Dr. Mouyad Al Samara and Dr. Ibrahim Elbadawi from the Economic Research Forum for their valuable comments of the draft version of this article.

\section{Conflict of Interest}

The authors declare that the research was conducted in the absence of any commercial or financial relationships that could be construed as a potential conflict of interest.

\section{Copyright and License}

This article is published under the terms of the Creative Commons

Attribution - NoDerivs (CC BY-ND 4.0) License

http://creativecommons.org/licenses/by-nd/4.0/

Published by Cracow University of Economics - Krakow, Poland 